\title{
The art education construction of woven craft society in Kudus Regency
}

\section{${ }^{E k o}$ Sugiarto ${ }^{1}$, Tjetjep Rohendi Rohidi ${ }^{1}$, Totok Sumaryanto Florentinus ${ }^{1}$, Dharsono Sony Kartika²}

\author{
${ }^{1}$ Post-graduate of Art Education, Universitas Negeri Semarang, Indonesia \\ ${ }^{2}$ Post-graduate, Institut Seni Indonesia Surakarta, Indonesia
}

Received: February 22, 2017. Revised: March 8, 2017. Accepted: May 12, 2017

\begin{abstract}
One example of society-based local art which is constantly enculturated is woven craft of Desa Jepang (Jepang Village) Kecamatan Mejobo in Kudus Regency. This paper aims at explaining the enculturation of woven craft grown in Jepang village Kudus Regency Central Java Province Indonesia as a form society-based art education. The approach employed in this study was qualitative with the cased study as the research design. Data were collected through observation, nonstructural interview, as well as documentation study with interactive model analysis. Research results show that art education grows within the society as the result of enculturation process of woven craft art in Jepang Village that takes place in the forms of: (1) the transmission of the craft skill and (2) the transmission of socio-cultural values. The transmission process is done between the old and young generations both in informal and non-formal ways. The woven craft of Jepang Village as an art product that has been enculturated is unique in terms of its form, media, technique, idea, as well as the modification aspects.
\end{abstract}

Keywords: woven; enculturation; society; art education

How to Cite: Sugiarto, E., Rohidi, T. R., Florentinus,T. S. \& Kartika, D. S. (2017). The art education construction of woven craft society in Kudus Regency. Harmonia: Journal of Arts Research And Education, 17(1), 87-95. doi:http://dx.doi. org/10.15294/harmonia.v17i1.8837

\section{Introduction}

Culture and education are two series of chain that cannot be separated from one to another. Education is even considered as a special means to pass certain culture down from one generation to the next generation (Rohidi, 2000). The definition implicitly means that the divertion of culture happens through the process of education.

Education is not only limited in a formal situation (education in public schools), but also includes education in informal and non-formal situations. These situations or scopes of education underlie the implementation of art education that results in the orientations of: (1) subject matter, (2) students, and (3) society (Soehardjo, 2011, p. 56). In the society-based education orientation, the art expression in a certain sub culture will be more developed, sedimented, and also rooted as a new life guidance. The life guidance here shows the relationship strength between human living in a certain culture with its environment, so that knowledge, practice, and belief are formed and adaptively developed through

\footnotetext{
${ }^{\square}$ Corresponding author: Jl. Kelud Utara III Semarang 50237

E-mail: ekosugiarto@mail.unnes.ac.id
} 
inherited process by a culture transmission (Bequette, 2017, pp.360-374).

As part of a bigger culture, art and education in a society cannot be separated from the dynamics and development caused by modernization. Clashes between one culture to another culture, or between traditional culture and a more popular culture also contribute to the development of arts in a society (Rohidi, 2000). Relationship between art expression and its environment is actually not only resulted from the dependency of human to their environment, but also the vice versa (Graham, 2007).

One of the society-based art product that is always preserved and developed through society education is woven craft in Jepang Village, Kecamatan Mejobo, Kudus Regency from bamboo as its main material. Bamboo has more than 1,250 varied species. They are different in its structure and form. The difference is caused by the ecological condition of the country, whether the region belongs to tropical and sub tropical or climated area (Setiawati, 2017).

The bamboo woven craft of Jepang Village is a manifestation of art education existence in society. This is an informal form of art education which has been existing in society for a long time. Previous researches related to art education representation in society has been informally done and concerned with various focuses.

Research from Joedawinata (2005) discussed the aspects of artefact manifestation in Cirebon. Woven artefact as a driver aspect from the local natural ecology aspect comprises the aspects of water, soil, air, and abiotic components, as well as other biotic components. The artefacts of etno-cultural-ecophenotipic as a utensil artefact is an idea and attitude transformation process of a community to be manifested as certain objects.

Karppinen (2008) in a research entitled "Craft-Art as a Basis for Human Activity" discusses craft and its correlation with art education in Finland through the conception of action. The aim of the research creates the model of skill education conception. The result shows that craft art is explored as a basic human activity. Further, Pöllänen (2009) also conducted a research entitled "Contextualising Craft: Pedagogical Models for Craft Education". It tells about craft education in Finland which is seen from many aspects. These changes are related to the independent position of art as school subject which contains the lesson about textile and technical work as an implementation of the holistical process of art in curriculum. This is, in the end, related to the question about how craft should be taught at school.

State of the art of the present research as the paradigmatic aspect and the implementation of art education in the society of woven craft artists living in Jepang Village which mainly focuses on the scope of knowledge enculturation, values, and skills from one generation to the next. The woven art in Jepang Village basically shows two basic dichotomic issues. In one perspective, the woven craft artist community in society faces the challenge of modern product which becomes the rival of traditional woven art product which is no longer famous in society. In other sides, there is also a continuous attempt from the artist community to maintain the existence of woven craft from old generation to the young one. This condition then builds the construction of art education.

This paper will discuss the woven art enculturation within the society living in Jepang Village, Kudus Regency, Central Java Province, Indonesia, as a form of society-based art education. Therefore, based on the context of socio-cultural transformation explained in this present study, it is seen that the hereditary system of woven craft in Jepang village is considerably important to be discussed since it is able to give a concrete understanding and a clear picture of the representation of art education in local community, especially the society lives in the sub-cultural area of Jawa Pesisir lor-tengah (The Mid-Northern Coast of Java). 


\section{Method}

This research employs qualitative method. Researcher understands the phenomena of woven art inheritance in the field, describes it deeply and thoroughly, and analyzes it from the context of its society (emic) and conceptual by the researcher (ethic). Design of the present research is case study on the collaboration between the school and the society. The research location is mapped in two big areas, from the geographical and cultural perspectives. Geographically, this research is located in Kudus Regency in Central Java, while from the cultural perspective, this research is located in the sub cultural area of the Mid-Northern (lor-tengah) side of Jawa Pesisir (Marshall \& Rossman, 2006; Miles, 1992; Lincoln \& Denzim, 2009).

Researcher uses the qualitative approach with case study design (see Denzim \& Lincoln, 1994; Sugiyono, 2008; Miles, 1992). There are four main subjects of the research, (1) the community of artist, (2) the community of user, (3) the local public figure, as well as (4) teacher and student at school (the source implicature of local wisdom).

The research location is focused on the area in Jepang village Kecamatan Mejobo Kudus Regency. The data is collected through observation technique, deep interview, and documentation study. Meanwhile, to validate the study results, source triangulation is employed. Data in this research is qualitative. Therefore, the analysis technique used in the study is the interactive analysis model, comprising: (1) data reduction, (2) data presentation, and (3) verification (Miles \& Huberman, 1992, p. 17).

\section{Results and Discussion}

\section{The Woven Craft of Jepang Village in Kudus} Regency

Anyaman or woven in the context of craft art actually refers to the "technique of making" that can be given an analogy as carving. The woven technique is a technique that can be used to make craft objects (both in two and three dimensions) through creating and forming bamboo sheets that are done by using the structural-constructive structure by referring to "even distribution of load" in a high level of flexibility. Most of this woven technique is applied in bamboo material (Joedawinata, 2005, p. 88).

Anyaman or woven is an old craft art. The existence has been found since the establishment of humankind civilization. The first woven craft used bamboo as its material. The type of bamboo tree used to do the weaving was bamboo apus or Gigantochloa Apus and bamboo wulu or Gigantochloa Atroviolacea. These types of bamboo plants were considered strong, flexible, and straight. It had a good quality to be used as the material of woven craft since the plant fiber was long, strong, and flexible (Setiawati, 2017).

The weaving technique is visually interlaced, without a beginning and without an end in construction. Similarly, the pattern and the weaving structure is not segmentaristic, but it is intertwined form one side to another side, so altogether they will form a certain pattern. In a formal aesthetic way, the forming structure of the weaving is considered rigid and made a recurred pattern. Futher, in terms of its aesthetic-formal, the form and structure of the weaving are very formalistic (See Bell in Sahman, 1993; Dharsono, 2004). The aesthetic-formalist builds the art excellency criteria on the quality of integrative formal arrangement of artwork that emphasizes on relations between visual aspects that is interconnected in a product of art.

The woven craft product in Jepang village is considered varied. The following is the matrix of woven craft products from Jepang village.

From the analysis results, it is found that the woven craft made in Jepang village in Kudus Regency can be divided into two groups, based on the technique/ media used to create the woven craft, and based on the purposes of weaving. First analysis will be about the weaving techni- 
Table 1. Matrix of Webbing Craft Types

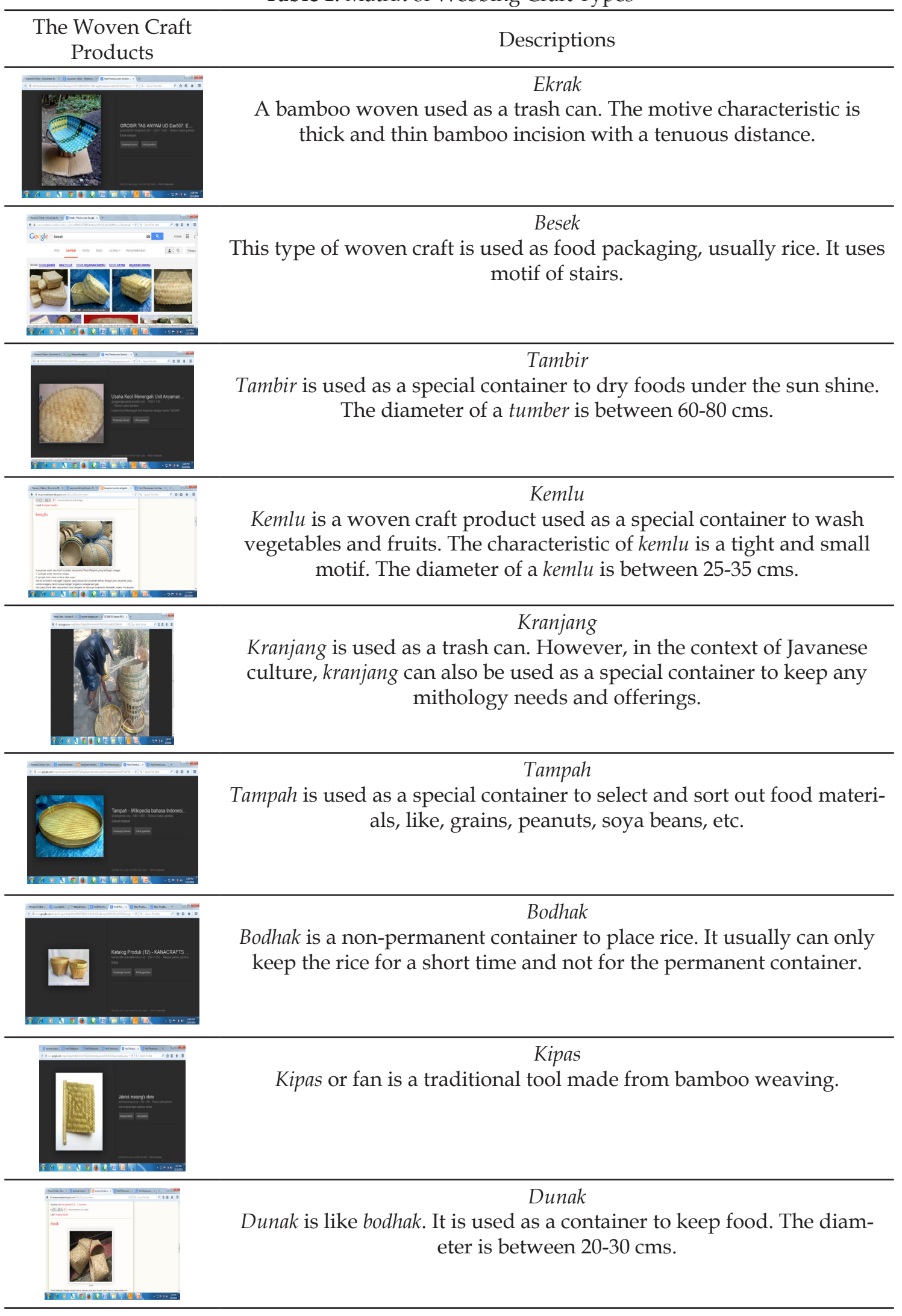


que/media which is further divided into, basic weaving, creation weaving, and innovation weaving.

Essential weaving is a kind of woven craft made as a complimentary product to fulfil the basic needs of Kudus people. This type of craft emphasizes on the domination of function or in another word, applicable. This product is widely known among Kudus people and the motif used is basic without modification. Usually, this type of weaving is used as household utensils and widely used as kitchen equipment and cleaning tools. Second, the creation weaving. This type of weaving has been added by modification and motifs. This type of weaving has both aesthetic and functional aspects in it. However, the creational woven craft products have similar forms with its basic shape. The third is the innovation weaving. Innovation weaving is a type of woven craft which has been significantly modified, both in terms of the technique used to create it and the materials used to make it. The innovation weaving is a transformative product. The most significant transformation lies on the use of materials to make it. The materials used to produce the woven craft product tends to be a plastic waste or other wastes. The orientation of production is shifted, from private consumption to mass consumption; and naturally profit oriented.

Second, based on the puposes of production, the woven craft from Jepang village can be divided into basic-needs weaving, aesthetical-needs weaving, and custom/belief-needs weaving. The woven craft production for basic needs manifests in the form of products used to help the people to do daily activities. Meanwhile, aesthetical weaving is closely related to the social aspect of Kudus society (Dharsono, 2004). Lastly, woven craft produced for custom or beliefs purposes is closely related to the tradition done by Kudus society in general, like, the tradition of burying baby's placenta after born which uses the kranjang weaving, the tradition of kenduri which uses besek weaving, as well as tumpengan tradition that uses tampah weaving.
In addition to this is caping (custom purposes) as the complimentary hat for Kudus traditional outfit.

Based on the findings and analysis mentioned and described earlier, the woven craft products from Jepang village can be syntesized into the following figures. The figure is created to show the conceptual mapping of woven craft types.

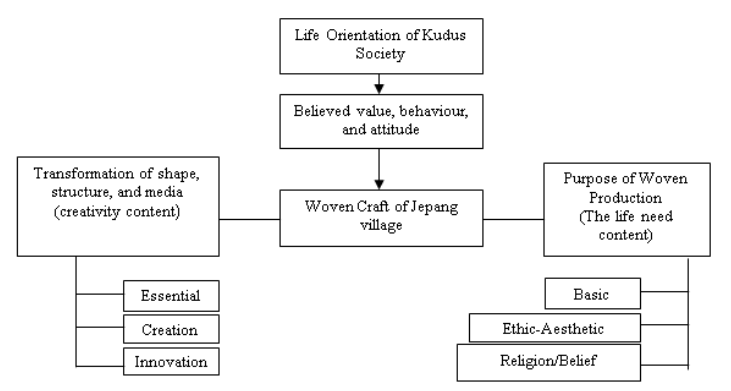

Figure 1. Mapping of Woven Types of Jepang village

The Ert Education Process in Woven Craft Enculturation in Jepang village of Kudus Regency Woven craft from Jepang village is inherited from the ancestors to the next generation in the scope of family and society. The inheritance process shows the presence of enculturation.

The enculturation of woven craft in Jepang village society is a form of societybased art education. The inheritance pattern of the craft is actually a representation of art education (that tends to be interpreted as skill transfer) that goes on explicitly. In inheritance system of woven craft in Jepang village society, there are two substansial transmissions attached, (1) the skill-technic transmission and (2) the value (enculturation) transmission. For Pöllänen (2009), art education in the society fully supports the contextualization of crafting education with a pedagogical model that establishes the holistical art conception.

First, the inheritance system of woven craft (the transmission aspect of technical skill) can not be separated from the ecological aspect in the context of sub-culture area of Javanese mid-western coast (pesisir lor-tengah). The cultural ecology tends to explain about causes of similarities and differences of socio-culture, as well as the 
connection between the ecology problem with the culture of a human. In the ecological culture perspective, the inheritance system of woven craft in Jepang village comprises the relationship between environment and technology, the relationship between behavioral pattern and technology, as well as an overview of a pattern of attitude that influences the other sectors within the culture. The social attitude in society always invites important meaning on the relation bertween the society themselves and the environment. According to Stewrd (Irianto, 2009, p.75), the basic assumption of the ecological and cultural theory is the environmental factors that have both positive and negative potentials in every cultural process. Rohidi (2011, p.155) states that in cultural ecological approach, art is placed as one of the fields of study which is related to the environments and its changes.

Secondly, the inheritence pattern of woven craft (value enculturation aspect) cannot be separated from the aspect of socio-cultural area context where Kudus is located in the mid-nortern coast of Java (pesisir lor-tengah). The essence of a true education is actually the value transfer in certain culture framework. In the inheritance system of woven art, there is an integration of value in inheriting the woven craft skill from one generation to the next generation. The interesting phenomenon is the possibility of socio-cultural value shifting within the supported society. This way, the value is implicated to the change of inheritance system of woven craft in Jepang village paradigmatically, comprising the believed concept, strategy, and the applied method.

The woven craft in Jepang village in Kudus Regency is a traditional fine art product in the sub system of the culture of society living in the mid-northern coast of Java Island. This socio-cultural aspect of culture cannot be separated from the dynamics and developments caused by the flow of change, and in that place, art is placing itself dynamically. Art is then inherited from one generation to the next generati- on through the process of education within the society. It gives implications to the system of behaviour, attitude, and values attached in the inheritance process of a cultural product that is inserted into the process of education in the middle of an existing change in society. This is directly and indirectly will create a pradigmatic pattern towards art education in the society in Jepang village through the inheritance (skills and values) of the woven craft.

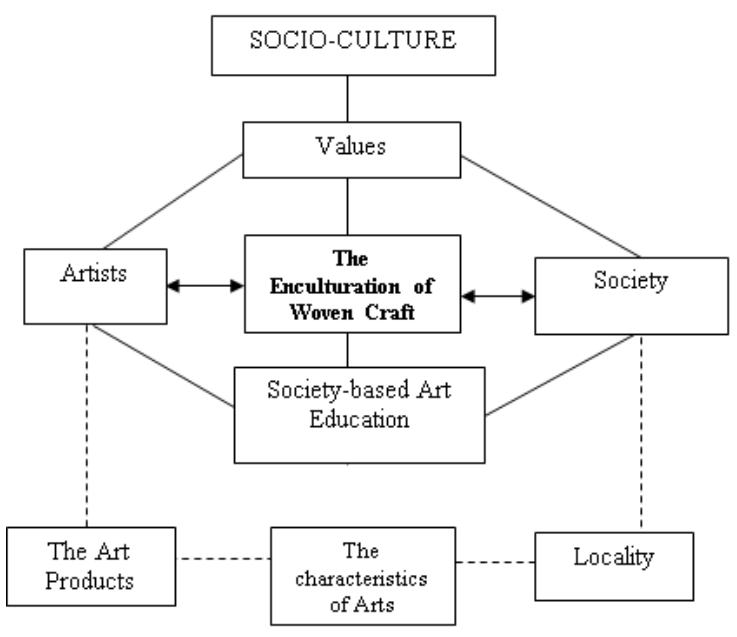

Figure 2. The Enculturation of Woven Craft in the Context of Art Education

In many social studies, the social change encompasses a wide area and even gives implication to the other fields. The social change is defined as variation and modification in every social process aspect, the social aspect, and social formations, as welll as "every modification of pattern between established inter-connected relations and standard of attitude" (see Laurer, 1993). In the case of woven craft inheritance pattern in Jepang village in Kudus Regency, the society (as the doer of every social interaction) with other institutions positioned as a whole, or in other words is considered as a "system" that is interrelated and later form systemic relations. For Parsons (1964, p.337), the change can be only understood through an understanding towards the former structures (see Rohidi, 2000).

The Art Education Construction (The Woven 


\section{Craft) in the Society}

Art Education is an integral part of education which generally accomodates the capacity of creative capacity and cultural awareness (Unesco, 2006). The term fine arts education in Indonesia has a similar understanding with the "Art Education" which is widely used in the U.S. and Europe. In conceptual understanding, the term Arts Education has grown and developed earlier in Western countries. An expert of Arts Education from America, Lansing (1969, p.268) in his book entitled "Art, Artist, and Art Education" state that to accomplish the absolute purposes of education through arts, one (student) should have the experience to work creatively and to appreciate the arts itself.

Another famous expert namely Read (1970, p.1) in his book entitled "Education Through Art", referred his understanding towards Art education by citing Plato's idea which says that 'arts has to be the basic of education'. Plato (Read, 1970, p.1) underlines the ideal potency and position of art education. In general, the art education conception which is based on the society needs sees that art education aims to fulfil the need of the society (Salam, 2001,p.13).

Arts and art education cannot be separated from the perspective of culture. Koentjaraningrat (1974) defines culture as a whole human activity formed by their ordered behavior and results of the behaviour that has to be obtained from learning and the society rules. The enculturation of woven craft in Jepang village as part of certain cultural products definetely gives implications in the practice of craft education both informally and non-formally. The craft art education in the area of Jepang village is, besides developes the technical skill of each individual while working, also emphasizes the aspect of artistical approaches and ideas. This is supported by Karppinen (2008) who states that craft education is a part of art education system that naturally has basic differences than the skills made in schools (formal education).

Woven craft is an art which has two major functions: as a cultural product (art) and as an educational media. The woven craft is supposed to be able to represent the culture of local society both from the form of the arts and its the visual structure, as well as to persuade the society. Based on the fact mentioned, therefore, the conception of art education in art education contains two substances, (1) an art skill as an ability that has to be inherited, and (2) an inheritance system and pattern. There is always values of life attached to it that has to be enculturated. In this conception, the cognitive aspect is reduced, the art skill aspect is explicitly dominant, and the value aspect is implicitly integrated into the teaching and learning process.

Paradigmatically, the believed conception will in the end result in the strategic implication and inheritance method pattern. First, the skill of doing arts is taught (1) non-formally from the generation who had previously learnt directly from the sources or nyantrik, (2) infromally from parents to the children by watching and immitating, (3) informally from the society living in surrounding neighbourhood, and (4) integrally from the art subject at school by involving the society and parents in it. Second, the value is inherited through the attitudes that are deliberately given to the next generation (the learners) from the elder generation (the teacher). Sillis (2000) mentions that the practical development in fine art education can be obtained through cross occupation cooperation between artwork project and mentor.

Hosang (2010) mentioned earlier that the relation between the art educators and the craft artists also gives a contribution towards the existence of art education. In woven craft education that happens within the society of Jepang village, there are several basic philosophical understanding that has to be answered: "who learns what?" and "who learns from whom?". First, crafting artists learned the skill of woven craft by invloving the aspect of the idea and media exploration (tool, material, and technique), so that the woven craft can be established. Second, the artists learned from the (1) consumers, about the taste of arts liked by them; (2) ancestors or previous generations about the skill of weaving; 
and (3) society in a broad sense, about the orientation shifting and life needs.

\section{Conclusion}

The craft products made in Jepang village shows uniquess in terms of its shape, media, technique, ideas, as well as its modification aspects that are continuously developed in an inheritance pattern. The inheritance system of woven craft in Jepang village is actually a representation of a bigger art education which contains two transmission substances, (1) the skilltechnical substance and (2) the value transmission (enculturation). The construction of art education in society, further, employs other two substances: (1) art skill as an ability which has to be inherited, and (2) within the inheritence system itself, there are life values attached to it that have to be enculturated. Paradigmatically, the believed conception itself, in the end, will give implication to the inheritance strategies and systems, both from generation to the next generation or from the perspective of the artists who had learnt the skill of weaving from direct ancestors. This then forms a model of art education construction within society.

\section{References}

Bequette, James W. (2007). Traditional Arts Knowledge, Traditional Ecological Lore: The Intersection of Art Education and Environmental Education. Journal A Studies in Art Education. 48(4), 360-374.

Graham, Mark A. (2007). Art, Ecology and Art Education: Locating Art Education in a Critical Place-based Pedagogy. Journal A Studies in Art Education. 48(4), 375-391.

Hosang, A. (2010). The art of making connection: Creating a window for cooperation between Artists and Teachers The Case of Seoul Foundation for Arts and Culture. Presented in Proceeding The 2nd World Conference on Arts Education (pp. 101-102). Seoul. Re- trieved from http://www.unesco. org/culture/en/artseducation/ pdf/presentation105hosangahn.pdf

Sillis, J. (2000). Non-formal training for arts education practitioners. In The 2nd World Conference on Arts Education (Vol. 1). Seoul: Cambridge University Press. Retrieved from http:// www.unesco.org/culture/en/artseducation/pdf/presentation107janesillis.pdf

Joedawinata, Ahadiat. (2008). Unsur-unsur Pemandu dan Kontribusinya dalam mewujudkan Sosok Artefak Tradisional dengan Indikasi-indikasi Lokal yang Dikandung dan Dipancarkannya. Jurnal Ilmu Desain, 3(2).

Karppinen, Seija. (2008). Craft-Art as a Basis for Human Activity. International Journal of Art and Design Education. 27(1).

Koentjaraningrat. (1974). Kebudayaan. Mentalitet, dan Pembangunan. Jakarta: PT Gramedia.

Lansing, Kenneth M. (1969). Art, Artist, and Art Education. New York: Mc Graw-Hill Book Company.

Laure, Robert H. (1993). Perspective on Social Change. Tranlated by Alimandan. Jakarta: Rineka Cipta.

Miles, H B. \& Heberman A M. (1992). Analisis Data Kualitatif (terj. Tjetjep Rohendi Rohidi). Jakarta: UI Press.

Parsons, Talcott. (1964). "A Funcional Theory of Change". Dalam Social Change. Editor Emitai dan Eva Etzioni. New York: Basic Books.

Pöllänen, Sinikka. (2009). Contextualising Craft: Pedagogical Models for Craft Education. International Journal of Art \& Design Education (JADE), 28(3).

Read, Herbert. (1970). Education through Art. London: Faber and Faber. (Cetak Ulang).

Rohidi, Tjetjep Rohendi. (2011). Metodologi Penelitian Seni. Semarang: Cipta Prima Nusantara Semarang.

Rohidi, Tjetjep Rohendi. (2000). Kesenian dalam Pendekatan kebudayaan. Bandung: STISI Bandung.

Salam, Sofyan. (2001). Pendekatan Ekspre- 
si-Diri, Disiplin, dan Multikultural dalam Pendidikan Seni Rupa. Jurnal Wacana Seni Rupa, 1(3),12-22

Setiawati, Tia, dkk. (2017). Species diversity and utilization of bamboo to support life's the community of Karangwangi Village, Cidaun Sub-District of Cianjur, Indonesia. Journal Biodiversitas, 18(1), 58-64.

Sillis, J. (2000). Non-formal training for arts education practitioners. In The 2nd World Conference on Arts Education (Vol. 1). Seoul: Cambridge University Press. Retrieved from http:// www.unesco.org/culture/en/artseducation/pdf/presentation107janesillis.pdf

Soehardjo, A J. (2011). Pendidikan Seni, dari Konsep Sampai Program (Buku I). Malang: Bayumedia Publishing.

Sugiyono. (2009). Metode Penelitian Kuantitatif, Kualitatif, dan R\&D. Bandung: Alfabeta.

UNESCO. (2006). "Road Map for Arts Education". Proceeding The World Conference on Arts Education: Building Creative Capacities for the 21 st Century, Lisbon, March 6 ${ }^{\text {th }}, 2006$. 